Jurnal Ekonomi dan Industri

e-ISSN : 2656-3169

Volume 20, No. 3, September-Desember 2019

p-ISSN : 0853-5248

\title{
PERAN MASYARAKAT LOKAL DALAM PENGEMBANGAN GEOSITE GEOPARK KALDERA TOBA SILAHISABUNGAN MENUJU GEOPARK GLOBAL UNESCO
}

\author{
Karmel Simatupang ${ }^{1}$ ) \\ 1) Dosen Program Studi Manajemen \\ Fakultas Ekonomi dan Ilmu Sosial Universitas Sari Mutiara Indonesia, Medan \\ e-mail: karmelsianturi@gmail.com \\ Roberto Roy Purba ${ }^{2}$ ) \\ 2) Dosen Program Studi Manajemen \\ Fakultas Ekonomi dan Ilmu Sosial Universitas Sari Mutiara Indonesia, Medan \\ e-mail: robertoroypurba@gmail.com
}

\begin{abstract}
This study aims to determine to which extent local communities are involved and play a role in the development of Toba Caldera Geopark (TCG) in the Silahisabungan geosite, Silahisabungan Sub-district, Dairi Regency, North Sumatra Province. The research method was conducted with a descriptive qualitative approach, by conducting literature studies, and field observations. The researcher acts as a participant-observer. This study found that the local communities of Silahisabungan generally did not understand about geopark, and its role in the development of Silabisabungan TCG geosite. This was mainly due to the lack of public knowledge about geopark and geosite. On the other hand the government is still reluctant to commit to allocate budgets in order to empower local communities. As TCG proposes to UNESCO Global Geopark, the Silahisabungan geosite has the potential in terms of geological, cultural and biological diversity that can be seeded. Therefore, the government and other parties concerned, it is very important to fully support the development of Silahisabungan geosite. Local communities should receive assistance and counseling on how to maximize the potential of their region with the principles of sustainable tourism.
\end{abstract}

Keywords: Local communities, silahisabungan geosite, toba caldera geopark.

\section{PENDAHULUAN}

Danau Toba dinobatkan sebagai danau vulkano-tektonik terbesar di dunia dan terluas di Asia Tenggara. Terletak di Provinsi Sumatera Utara, berukuran 100 x $30 \mathrm{~km}^{2}$, berada pada ketinggian 904 meter dpl dengan kedalaman danau mencapai 505 meter. Kaldera (baca; kawah) Danau Toba, itu adalah kaldera gunung api raksasa yang pernah meletus hebat sehingga mengubah iklim dunia dan nyaris menamatkan umat manusia. Sekitar 74.000 tahun lampau, Gunung Toba meletus hebat (supereruption), mengirim awan panas raksasa yang menutup nyaris seluruh ujung timur hingga barat Pulau Sumatera. Erupsi magma nya mencapai $2800 \mathrm{~km}^{3}$, dengan indeks erupsi mencapai skala magnitudo 8,8 sehingga tergolong sebagai letusan paling dahsyat dalam sejarah planet bumi (Craig A. Chesner, 2011).

Jutaan kubik abu dimuntahkan, menutupi Lautan Hindia hingga Laut Arab dan sebagian Samudera Pasifik. Aerosol asam sulfat yang dilepaskan kemudian menyebar luas ke atmosfir dan menutupi bumi hingga menciptakan kegelapan total selama enam tahun. Migrasi manusia pun terhenti dan mereka terisolasi di Afrika, seperti yang terekam dalam kemiripan genetika manusia modern di seluruh penjuru dunia (Kompas TV, 2011). 
Menciptakan fenomena alam, yakni Danau Toba yang sangat luar biasa. Kawasan ini memiliki kekayaan keanekaragaman geologi berupa bentang alam dan jenis batuan, keanekaragaman budaya serta hayati yang sudah dikenal secara internasional. Anugerah keanekaragaman geologi Kaldera Toba ini mengandung nilai Warisan Geologi (geoheritage). Kawasan ini sangat berpotensi sebagai destinasi pariwisata berkelas dunia, dan sangat layak menjadi anggota geopark (taman bumi) global.

Oleh karena itu tidak mengherankan, bila pemerintah sejak tahun 2011, melalui Kementerian Pariwisata dan Ekonomi Kreatif mulai mengenalkan dan mempersiapkan Kawasan Danau Toba (KDT) sebagai kandidat geopark nasional, dan selanjutnya diusulkan menjadi anggota Geopark Global UNESCO (GGU).

Kawasan geopark itu sendiri adalah wilayah geografis tunggal yang memiliki situs dan bentang alam bernilai internasional, dikelola dalam konsep perlindungan atau konservasi, pendidikan dan pembangunan berkelanjutan secara holistik menurut (UNESCO, 2006). Kawasan geopark tersebut dikembangkan melalui proses bottom-up dan harus melibatkan masyarakat lokal sebagai stakeholder utama.

Peran masyarakat lokal dalam pengembangan kawasan geopark adalah menjadi penentu keberhasilan tujuan geopark, sebab masyarakat lokal yang hidup dan berpengalaman di wilayahnya, sesuai dengan adat-istiadatnya. Dengan kata lain, kawasan geopark di suatu daerah sulit berhasil jika masyarakat lokalnya kurang terlibat dan berperan. Selain indikator keberhasilan geopark itu sendiri adalah terlihat dari peningkatan kesejahteraan masyarakat lokal, melalui aktivitas pariwisata berbasis geopark, dan terkonservasinya situs-situs budaya, hayati dan geologi di daerah tersebut (Suwardi, Sofyan, 2016).

Secara umum masyarakat lokal di setiap geosite Geopark Kaldera Toba (GKT) masih merasa kurang dilibatkan sejak dalam perencanaan hingga pengembangan sehingga rasa memiliki GKT terasa kurang kuat. Pada penelitian ini penulis memfokuskan objek penelitian peran serta masyarakat lokal dalam pengembangan salah satu geosite (situs GKT) dari 16 geosite GKT yang ada di seluruh kawasan GKT.

Berdasarkan uraian latar belakang di atas maka dapat dirumuskan masalah dalam penelitian ini, yakni seperti apa masyarakat lokal terlibat dan berperan dalam pengembangan geopark di geosite Silahisabungan, Kecamatan Silahisabungan, Kabupaten Dairi, Provinsi Sumatera Utara?

Adapun tujuan penelitian adalah untuk mengetahui sejauh mana masyarakat lokal terlibat dan berperan dalam pengembangan geopark di geosite Silahisabungan, Kec. Silahisabungan, Kab. Dairi, Provinsi Sumatera Utara.

\section{LANDASAN TEORI}

\section{Konsep Geopark}

Seperti disebutkan dalam latar belakang, bahwa Kawasan Geopark itu sendiri adalah wilayah geografis tunggal yang memiliki situs dan bentang alam bernilai internasional, dikelola dalam konsep perlindungan atau konservasi, pendidikan dan pembangunan berkelanjutan secara holistik (UNESCO, 2006). Terdapat tiga komponen dasar keragaman dalam kawasan geopark; yakni geologi, hayati dan budaya. Ketiga unsur alam tersebut tidak berdiri sendiri -sendiri, namun cenderung saling berhubungan. Kawasan geopark tersebut dikembangkan melalui proses bottom-up dan harus melibatkan masyarakat lokal sebagai stakeholder utama dan stakeholder lain yang terkait. Artinya, pembangunan dan pengembangan geopark itu sebenarnya 
memerlukan kerjasama banyak pihak (multistakeholder), dengan masing -masing pihak merefleksikan "siapa" berbuat "apa" (Sofyan, dkk, 2016).

Adapun geosite merupakan lokasi yang memiliki signifikansi secara geologi atau geomorfologi, serta karakteristik geologis yang melekat, dan mungkin juga memiliki signifikansi budaya atau warisan. Secara sederhana geosite dapat diartikan sebagai situssitus geopark, seperti situs geologi, budaya dan hayati yang dijadikan sebagai destinasi baru wisata.

\section{Geopark Global UNESCO}

GGU adalah wilayah geografis, tunggal dan terpadu dimana situs dan lanskap geologi yang memiliki signifikansi internasional dikelola dengan konsep holistik meliputi perlindungan, pendidikan dan pembangunan berkelanjutan. GGU merupakan jaringan dinamis di mana anggotanya mempunyai komitmen untuk bekerja sama dan bertukar pikiran tentang praktek-praktek terbaik. Kerjasama itu terwujud dalam proyek-proyek umum, yang bertujuan meningkatkan standar kualitas dari semua produk dan kegiatan penyelenggaraan geopark global.

UNESCO mulai bekerja dengan geopark sejak 2001. Pada 2004, terbentuk Jaringan Geopark Global (Global Geopark Network). Sejak 17 November 2017, 195 anggota GGN meratifikasi label baru, dengan nama Geopark Global Unesco (UNESCO Global Geoparks). Saat ini terdapat 140 GGU di seluruh dunia di 38 Negara. Indonesia kini sudah memiliki 4 anggota GGU, yakni geopark global Batur, Gung Sewu, Ciletuh dan Gunung Rinjani.

\section{Karakteristik Wilayah}

Kawasan Kaldera Toba adalah sebuah kesatuan ekosistem geologi, biologi dan budaya. Segala sesuatu yang terjadi di kawasan ini akan berdampak langsung terhadap kelestarian ekosistem Danau Toba itu sendiri. Degradasi lingkungan Kawasana Danau Toba dalam 3 dekade terakhir, baik dalam dan luar danau turut mengancam kelestarian situs-situs hayati, budaya dan geologi sekitarnya. Itu sebabnya, kawasan ini sangat cocok dikembangkan dengan konsep geopark, sebagai model pembangunan berkelanjutan secara integral-holistik yang mengkonservasi ketiga kesatuan di atas.

Dari segi etnisitas, Kawasan GKT adalah tanah leluhur masyarakat Adat Batak, yang terdiri dari 4 subetnik, yakni Toba, Karo, Simalungun dan Dairi, dengan total populasi sekitarnya berkisar 2,2 juta jiwa (BPS, 2012).

Kawasan GKT tersebut meliputi area seluas $3.658 \mathrm{Km}^{2}$, mencakup 7 Kabupaten, yaitu: Karo, Dairi, Simalungun, Toba Samosir, Tapanuli Utara, Humbang Hasundutan (Humbahas), dan Samosir. Saat ini, terdapat 16 Geosite utama GKT yang tersebar di 7 Kabupaten.

Dalam penelitian ini, peneliti membatasi fokus penelitian, yakni pada peran serta masyarakat untuk mengembangkan geosite Silahisabungan, di Kabupaten Dairi.

\section{GKT Menuju GGU}

GKT ditetapkan secara resmi sebagai Geopark Nasional pada Tanggal 7 Oktober 2013 oleh Direktur Jenderal Pengembangan Destinasi Pariwisata Kementerian Pariwisata dan Ekonomi Kreatif, dan Kepala Badan Geologi, Kementerian Energi Sumber Daya Mineral. Kemudian dikukuhkan Presiden Susilo Bambang Yudhoyono, 27 Maret 2014. GKT selanjutnya didaftarkan untuk menjadi salah satu anggota UGG, pada Bulan November 2014, bersamaan dengan pengusulan Geopark Gunung Sewu. Namun, dalam pengumuman Simposium Asia Pacific Geopark Network 
(APGN) ke-4 di Jepang, 19 September 2015, GKT tidak berhasil diterima sebagai anggota UGG karena dianggap belum matang. Adapun Geopark Gunung Sewu menjadi anggota UGG ke-2 di Indonesia, setelah Batur Global Geopark, 2012.

UGG kemudian memberikan 5 rekomendasi kepada Pemerintah Indonesia melalui delegasi Tim GKT Nasional. Inti rekomendasi tersebut adalah agar GKT harus operasional dulu di lapangan, yakni adanya aktivitas edukasi terpadu, pembenahan panel-panel edukasi geosite GKT dengan informasi tematik dan mudah dipahami pengunjung, strategi pemasaran dan promosi, strategi pengembangan wisata budaya, serta aktivitas geopark harus sudah terjadi di lapangan.

Dalam suratnya tertanggal 5 Oktober 2015, GGU memberikan waktu tenggang 2 Tahun, Pemerintah Indonesia dapat mendaftar kembali GKT ke UGG, dengan catatan telah memenuhi ke-5 rekomendasi UNESCO tersebut.

Adapun Pemerintah Sumatera Utara, telah mengeluarkan Peraturan Gubernur No. 34 Tahun 2015, tentang Badan Pengelola Geopark Kaldera Toba dan SK Gubsu No. 188.44/5KPTS/2016 tentang Badan Pelaksana dan Kelompok Pakar Geopark Kaldera Toba (BP-GKT), yang personilnya dilantik 1 Februari 2016.

Pada 29 November 2017, Pemerintah Indonesia melalui Komite Nasional Indonesia untuk Unesco (KNIU) telah mengirimkan kembali dokumen usulan (dossier) GKT ke sekretariat GGU di Paris, Perancis. Pengusulan ini sesuai tenggang waktu rekomendasi UNESCO. Tentunya Pemerintah Indonesia, dan masyarakat sangat mengharapkan GKT dapat lolos menjadi anggota GGU, yang akan diketahui pada September 2019 mendatang.

\section{Masyarakat Lokal}

Masyarakat lokal (Masyarakat Adat/Tradisional), menurut Oding, 2002 adalah; Suatu komunitas yang memiliki asal-usul leluhur secara turun-temurun, hidup di wilayah tertentu, memiliki sistem nilai, ideologi, sistem politik, budaya dan sosial yang khas. Mereka ada sebelum RI ini berdiri.

Sesuai dengan pengertian di atas, masyarakat lokal di Kawasan GKT, khususnya di geosite Silahisabungan adalah masyarakat atau komunitas yang memiliki asal -usul leluhur secara turun-temurun, hidup di wilayah tersebut, memiliki sistem nilai, ideologi, sistem politik, budaya dan sosial yang khas. Masyarakat lokal memiliki pengalaman dan pengetahuan hidup di daerah tersebut, dan mengetahui secara jelas bagaimana mengelola daerah tersebut. Oleh karena itu, sangat diperlukan dukungan pemerintah dan pihak swasta lainnya kepada masyarakat lokal, dengan sendirinya mereka bisa melakukan konservasi kawasan tersebut.

Seperti dibahas dalam latar belakang, bahwa masyarakat lokal dalam kawasan merupakan pelaku utama yang melakukan aktivitas konservasi, edukasi, dan akhirnya mengangkat ekonomi mereka melalui aktivitas pariwisata geopark, yakni geowisata. Geowisata merupakan kegiatan wisata yang berbasis pada objek -objek kebumian, air terjun, sungai, mata air, jenis batuan, lembah ataupun bentang alam (Heryadi: 2011).

\section{METODE PENELITIAN}

\section{Tahapan Penelitian}

Tahapan penelitian ini dilakukan pertama-tama dengan melakukan studi pendahuluan untuk menemukan masalah dan fokus penelitian. Kemudian menentukan pendekatan penelitian yakni kualitatif, lokasi penelitian dan teknik pengumpulan data. Lalu menyajikan data, dan melalukan analisis deskriptif serta menarik kesimpulan. 


\section{Teknik Pengumpulan Data}

Teknik pengumpulan data dilakukan dengan studi literatur, buku -buku yang relevan, dokumen, jurnal dan berita surat kabar serta melakukan observasi lapangan. Kemudian akan melakukan wawancara tidak berstruktur dengan perwakilan masyarakat lokal, Manager Geosite GKT Silahisabungan, Kepala Desa, Pemerintah Kabupaten Dairi dan komunitas yang peduli dengan pariwisata Silahisabungan. Tujuan menggunakan wawancara tidak berstruktur adalah dalam rangka mendapatkan eksplorasi mendalam terhadap fokus dan pertanyaan penelitian, (Riddell, 2004:287).

\section{Analisa Data}

Analisis data dilakukan dengan pendekatan deskriptif kualitatif. Peneliti bertindak sebagai participant-observer. Sejak 2013-2014, peneliti telah ikut bergabung sebagai anggota Tim Percepatan Pengajuan GKT ke UNESCO. Kemudian 2016 -2017, sebagai Pengurus Badan Pelaksana Geopark Kaldera Toba (BPGKT), memiliki banyak kesempatan bertemu dengan masyarakat lokal, pemerintah daerah dan pemerhati GKT, sehingga sebagian data sudah terkumpul sebagai dokumen pribadi. Data -data tersebut kemudian dikompilasi dan dianalisis secara interpretatif.

\section{HASIL DAN PEMBAHASAN}

\section{Peran Masyarakat Lokal}

Salah satu tujuan dari kawasan geopark adalah untuk menggali kembali kearifan lokal yang sesuai untuk melindungi kawasan tersebut. Itu sebabnya dalam konsep GGU sangat ditekankan bahwa masyarakat lokal, khususnya masyarakat adat harus aktif terlibat dalam mengatur, memelihara, dan merayakan kebudayaan mereka sebagai stakeholder kunci dalam wilayah geopark. Dengan keterlibatan masyarakat lokal, GGU mengakui pentingnya keberadaan komunitas masyarakat lokal, kebudayaan mereka, serta hubungan antara komunitas dan tanah tempat tinggal mereka.

Seperti disebutkan sebelumnya, bahwa masyarakat lokal dalam kawasan geopark merupakan pelaku utama yang melakukan aktivitas konservasi, edukasi, yang akhirnya akan mengangkat ekonomi mereka melalui aktivitas pariwisata berbasis geopark, seperti geowisata. Sedangkan pemerintah pada intinya berperan sebagai fasilitator pengembangan geosite geopark tersebut.

Filosofi geopark, dengan kata lain jelas tentang peran masyarakat lokal, mulai dari keterlibatan hingga partisipasi aktif dalam perencanaan dan pengembangan, yang sebagai imbalannya meningkatkan kepedulian terhadap lingkungan hidup. Ini adalah pengingat bahwa "Geoparks bukan hanya tentang batu, mereka adalah tentang manusia. Sangat penting bahwa mereka terlibat. Kami ingin melihat sebanyak mungkin orang keluar dan menikmati geologi daerah tersebut. Tujuan kami adalah untuk memaksimalkan geowisata (...) untuk kepentingan ekonomi lokal dan untuk membantu orang memahami evolusi lanskap lokal mereka," (Chris Woodley-Stewart, Geopark Manager, North Pennines AONB, United Kingdom).

Berdasarkan observasi lapangan dan wawancara yang dilakukan penulis kepada masyarakat Desa Paropo dan Silalahi 3, Kecamatan Silahisabungan, bahwa masyarakat secara umum sesungguhnya belum memahami tentang apa itu geopark dan peran serta nya dalam pengembangan geosite GKT Silahisabungan.

"Sebagai warga lokal, bagaimana kita bisa bicara tentang geopark, kita masih belum tahu apa itu geopark. Misalnya begini, ketika mereka (pemerintah) datang, kita hanya ditunjuk itu geosite, tapi kita tidak dijelaskan bagaimana mengetahui itu geosite 
(situs-situs geopark), apa itu geosite, intinya kami belum mengerti sebenarnya apa itu geopark. Di Desa Paropo itu cuma ada 1 plang (geosite), tapi secara jujur, itu plang tidak diketahui masyarakat. Artinya masyarakat kurang dilibatkan ketika itu dibuat. Kalo ada 300 orang masyarakat Desa Paropo, paling 15 orang yang mengetahui Paropo bagian kawasan geopark," kata Hermanto Situngkir, warga Desa Paropo, pemilik usaha Sipartogi Camp Desa Paropo, (27/6/2019).

Pemerintah, menurut pengakuan Hermanto, sebenarnya pernah melakukan sosialiasi, tetapi dilakukan di hotel dan sekolah, sementara orang-orangnya dipilih sebagian besar perangkat desa, sehingga kebanyakan kurang diketahui masyarakat. Oleh karena itu, pendekatan pemerintah seharusnya langsung kepada masyarakat, lalu kemudian ditindaklanjuti berupa pendampingan kepada masyarakat.

Pada sisi lain, masyarakat Silahisabungan sebenarnya dari kebiasaan mereka telah melakukan esensi geopark itu sendiri, sekalipun kurang mengetahui hal itu mendukung geopark. Prinsip konservasi misalnya. Menurut Hermanto, sesuai karakter topografi perbukitan Kecamatan Silahisabungan tidak banyak ditumbuhi pepohonan, namun di perladangan warga, cukup banyak terlihat pohon yang ditanam warga, seperti pohon Mangga. Hal lain dalam mengantisipasi longsor, masyarakat lokal punya kearifan menyusun batu-batuan sebagai tembok di perladangan dengan menggunakan tangan sendiri. Itu artinya masyarakat berkontribusi melakukan konservasi lingkungan.

Manager Geosite Silahisabungan, Rikson Sihombing, mengungkapkan bahwa masyarakat sesungguhnya sangat mendukung GKT, namun dukungan pemerintah dalam komitmen anggaran masih sangat kurang. Pemerintah hanya melakukan sebatas sosialisasi.

"Peran masyarakat lokal sebenarnya tinggi ketika kita motivasi bahwa akan ada pengembangan lokasinya menjadi situs geopark. Misalnya dengan memberikan jalan setapak dari tanahnya ke lokasi situs. Namun ternyata dukungan pemerintah (Pemerintah Provinsi Sumut) kepada manager geosite, Badan Pengelola Geopark Kaldera Toba (BPGKT) untuk pembenahan geosite hanya sekedar janji, tidak ada kelanjutan nya, sehingga masyarakat pun kurang tertarik dengan geopark, "kata Sihombing, (28/6/2019).

Timbul Situngkir (41), warga Desa Silalahi 3 juga mengakui bahwa pengetahuan masyarakat tentang geopark memang masih cukup terbatas. Itu karena masih kurangnya aksi nyata bagaimana manfaat geopark benar-benar bisa dirasakan masyarakat. Namun, kata Timbul, satu hal yang membanggakan saat ini di geosite Silahisabungan adalah adanya peran komunitas Seni Budaya yang turut mendukung kegiatan wisata dengan konsep geopark. Komunitas yang dimaksud adalah Rumah Karya Indonesia (RKI). RKI adalah sebuah komunitas pegiat seni budaya yang terdiri dari kaum muda milenial dari beragam latar belakang, dan bermarkas di Kota Medan, Sumatera Utara. Sejak Tahun 2016, RKI menggagas kegiatan Silahisabungan Arts Festival (SAFe) berlokasi di Desa Silalahi 3, dan Paropo. Kegiatan ini pada intinya lahir dari semangat geopark.

Menurut Situngkir, dari kegiatan inilah masyarakat terpapar tentang manfaat daerahnya jadi destinasi wisata baru seperti dalam konsepsi geopark. "Manfaat yang dirasakan masyarakat sejauh ini adalah, yang tidak berjualan jadi berjualan. Masyarakat, seperti saya sendiri, buka setiap hari, dulunya saya hanya bekerja di ladang," cerita Timbul, pemilik warung di lokasi kemping Pulau Silalahi (28/6/2019).

Arki Situngkir (25), warga Desa Paropo juga mengakui, bahwa dari kegiatan RKI "1000 Tenda" di Silalahi-Paropo baru mendengar tentang geopark. "Pengetahuan masyarakat sangat sedikit tentang geopark. Belum juga ada pemberdayaan masyarakat tentang hal itu, dari kegiatan 1000 Tenda, tempat ini jadi terkenal, disitu ada disebut geopark," kata Arki. 
Direktur RKI, Manalu (32), menjelaskan, bahwa RKI melaksanakan kegiatan nya, berdasarkan gagasan, latar belakang dan cara kerja geopark. RKI mengambil peran dengan praktek langsung turunan konsep geopark; yakni efeknya terhadap budaya, edukasi dan peningkatan ekonomi lokal. Mereka memilih Silalahi karena tertarik dengan alam dan situs budaya Silalahi.

"Peran RKI adalah langsung mempraktekkan cara kerja geopark lewat kegiatan seni dan budaya, menggali kearifan lokal yang ada, seperti mengangkat cerita opera Batak Raja Silahisabungan ke dalam pentas seni festival dengan kerjasama warga setempat. Masyarakat sangat welcome, sebab dilakukan bersama-sama dengan masyarakat. Pelaksanaan kegiatan '1000 Tenda' tahun 2019 ini, sudah langsung dikomandoi masyarakat setempat," kata Marojahan, (16/7/2019).

Silalahi Arts Festival yang kini berganti nama menjadi Tao Silalahi Arts Festival (TSAF) menjadi ajang festival tahunan yang dinanti-nantikan, khususnya kaum muda. Desa Silalahi 3 dan Desa Paropo kini menjadi tempat pekemah (camping ground) favorit ratusan milenial setiap minggunya.

Belajar dari apa yang dilakukan RKI di geosite Silahisabungan, masyarakat sebenarnya tidak susah diajak untuk terlibat dalam membangun kegiatan berbasis geopark, asalkan dilakukan bersama-sama dengan masyarakat, dan berasal dari bawah atau melalui proses bottom-up. Desa Silalahi 3 dan Paropo sebelumnya jarang dikunjungi pengunjung, namun kini menjadi tempat favorit kalangan muda. Masyarakat mau terlibat tak kala diikuti dengan manfaat ekonomi yang didapatkan.

\section{Peran Pemerintah}

Sebagaimana disebutkan di awal, pembangunan dan pengembangan geopark memerlukan kerjasama banyak pihak dan interkoneksi lembaga pemerintahan dari pusat hingga daerah sebagai fasilitator pemberdayaan masyarakat. Pemerintah Desa, Kabupaten, Provinsi dan Pusat tentunya memiliki tanggungjawab untuk memberikan pelatihan, sosialisasi, dukungan dana, hingga membentuk wadah tertentu yang berfokus, misalnya kelompok sadar wisata (Pokdarwis). Kolaborasi antara pemerintah dan masyarakat inilah yang kemudian akan menjadi iklim yang baik untuk memajukan sebuah kawasan destinasi.

Dalam undang-undang (UU) Desa dan UU Kepariwisataan, pemerintah sebetulnya memiliki tanggung jawab untuk memberdayakan masyarakat lokal. UU Nomor 6 Tahun 2014 tentang Desa, mengatur bahwa kepala desa mengemban tugas untuk melakukan pemberdayaan masyarakat melalui potensi lokal yang ada. Sedangkan dari UU Nomor 10, Tahun 2009 tentang Kepariwisataan, Pasal 30, Pemerintah Kabupaten berwenang untuk membentuk, melatih, dan mengembangkan Pokdarwis pada daerah yang memiliki potensi wilayah melalui dinas pariwisata sehingga dapat mengelola wisata dengan mandiri. Selain dari pada itu juga, ada organisasi PKK di desa yang berpotensi sebagai wadah untuk pemberdayaan. Oleh karena itu, peran serta masyarakat juga sangat dipengaruhi oleh pemerintah melalui beberapa kegiatan edukasi agar masyarakat memiliki modal pengetahuan yang adaptif terhadap perkembangan daerahnya.

Kepala Seksi Pemasaran Pariwisata, Pemerintah Kabupaten Dairi, M. Tampubolon menyampaikan bahwa pihaknya telah melakukan beberapa hal terkait dengan pengembangan geosite Silahisabungan. Diantaranya adalah pengadaan plang merk tentang geopark, pembuatan jalan setapak geopark di Desa Paropo induk, dan situs "Aek Sipaulak Hosa" yang merupakan bagian dari geosite Silahisabungan. Selain itu, sosialisasi tentang GKT sudah pernah dilakukan, termasuk oleh Pemerintah Provinsi Sumut.

"Dukungan Pemkab Dairi ke Kecamatan Silahisabungan, meski tidak secara langsung ke geopark namun mendukung pariwisata di Silalahi, salah satunya akan 
dibangun dermaga wisata di Silalahi 2, sebesar Rp. 4,2 Miliar, tahun 2019 ini mulai pembangunannya. Itu mendukung juga ke geopark karena geopark dan pariwisata tidak bisa dipisahkan," kata M. Tampubolon, (28/6/2019).

Adapun pokdarwis, di Kecamatan Silahisabungan, ungkapnya, saat ini masih hanya terdapat di Desa Silalahi 2, sebanyak 2 kelompok, sementara di desa lainnya belum terbentuk. Padahal, Pokdarwis ini sangat diperlukan sebagai pelopor dalam menggerakkan potensi desa tersebut. Adapun, Pemerintah Provinsi Sumut sejauh ini, hanya melakukan sosialisasi tentang geopark di sekolah-sekolah. Kata Tampubolon, Kementerian Pariwisata, pada Bulan Juni 2019 yang lalu, telah memberikan fasilitas homestay guna mendukung desa wisata di Desa Silalahi 2 dan Silalahi 1.

\section{Potensi Geosite menuju GGU}

Kecamatan Silahisabungan terbentang antara 024840.96 LU dan 9831 19.28 BT dengan ketinggian 956 dari atas permukaan laut dengan luas wilayah $75.62 \mathrm{~km} 2$ dan jumlah penduduk 5.319 jiwa, berada persis di bibir kaldera sebelah utara Danau Toba. Dapat ditempuh sekitar 3 jam melalui jalur darat dari Kota Medan yang merupakan salah satu kecamatan dari total 15 kecamatan Kabupaten Dairi, Provinsi Sumatera Utara.

Berkaitan dengan pengusulan GKT menjadi anggota GGU, geosite Silahisabungan memiliki potensi besar menjadi desa wisata berstandar geosite geopark global. Dari segi keragaman geologi, hayati dan budaya, geosite Silahisabungan memilikinya lengkap. Geosite Silalahisabungan merupakan bagian dari letusan gunung Toba purba periode 74.000 tahun lampau, yang dikenal sebagai super-volcano atau terkuat dalam sejarah letusan di planet ini.

Dari sisi budaya, geosite Silahisabungan punya keunikan tersendiri, yakni dengan keberadaan bahasa "sitolu huta" atau tiga bahasa berbeda yang dipakai dalam interaksi komunikasi sehari-hari. Tiga bahasa tersebut adalah Toba, Simalungun dan Karo. Masingmasing warga umumnya menguasai ketiga bahasa tersebut. Selain itu, terdapat makam Tugu Raja Silahisabungan yang merupakan asal usul nenek moyang Marga Batak Silalahi. Setiap tahun tugu ini selalu dirayakan pesta budaya, dengan kepanitiaan bergilir setiap keturunannya, hal ini potensial dikembangkan wisata budaya. Begitupun dengan kekayaan hayati, seperti Mangga Silalahi yang khas rasa dan ukurannya. Bawang Silalahi yang hanya tumbuh di sela-sela bebatuan Toba.

Adapun, tantangan yang harus diatasi adalah tentang keberadaan keramba jaring apung (KJA). Sebagai destinasi wisata geopark, tentunya hal ini bertentangan dengan prinsip-prinsip konservasi dan pembangunan berkelanjutan. KJA di Kecamatan Silahisabungan terdapat di Desa Paropo, Silalahi 3 dan Silalahi 1. Kepala Desa Silalahi 3, Rincon Situngkir, mengaku masih dilematis terkait dengan kebijakan membebaskan Danau Toba dari KJA. "Perlu ada pertimbangan matang tentang kebijakan KJA, dengan membuat zonasi, karena masyarakat disini hidup dari KJA yang pemiliknya adalah warga, seperti di Desa Silalahi 3, jadi belum bisa langsung diberhentikan semua," kata Rincon via telepon, $(13 / 7 / 2019)$.

\section{KESIMPULAN DAN SARAN}

Masyarakat lokal dalam kawasan geopark, merupakan stakeholder utama yang menjalankan aktivitas seperti edukasi, konservasi dan pembangunan berkelanjutan sebagaimana konsep geopark. Dengan kata lain, filosofi geopark jelas tentang peran masyarakat lokal, mulai dari keterlibatan hingga partisipasi aktif dalam perencanaan dan pengembangan, yang sebagai imbalannya meningkatkan kepedulian terhadap lingkungan 
hidup. Geosite Silahisabungan merupakan satu dari 16 geosite GKT yang telah diajukan Pemerintah Indonesia untuk menjadi anggota GGU, 29 November 2017. Meskipun inisiasi GKT telah dimulai sejak 2011, peran-serta masyarakat lokal di seluruh kawasan GKT masih belum terlihat signifikan. Hal ini diketahui, karena geopark belum memberikan manfaat peningkatan ekonomi bagi masyarakat, di sisi lain pemerintah juga masih enggan berkomitmen mengalokasikan anggaran dalam rangka pemberdayaan masyarakat setempat.

Berdasarkan temuan penelitian ini, bahwa masyarakat lokal geosite Silahisabungan umumnya belum paham tentang geopark, dan peran sertanya dalam pengembangan geosite tersebut. Hal ini terutama disebabkan pengetahuan masyarakat tentang geopark dan geosite masih minim. Pemerintah melakukan sosialisasi geopark dan menjadikan Kecamatan Silahisabungan salah satu geosite GKT, namun kurang melibatkan masyarakat lokal sejak dari awal, bagaimana melakukan konservasi, edukasi, yang akhirnya berdampak pada peningkatan ekonomi lokal. Padahal, kebiasaan masyarakat lokal sesungguhnya sudah memiliki kearifan dalam melakukan prinsip geopark seperti konservasi alam. Hal ini yang seharusnya digali dan dikembangkan lebih jauh serta difasilitasi pemerintah.

Namun hal yang menggembirakan di geosite Silahisabungan adalah adanya peran komunitas Seni Budaya yang turut mendukung kegiatan wisata dengan konsep geopark. Komunitas tersebut adalah Rumah Karya Indonesia (RKI). Sejak Tahun 2016, RKI menggagas kegiatan Silahisabungan Arts Festival (SAFe) berlokasi di Desa Silalahi 3, dan Paropo. Kegiatan ini pada dasarnya lahir dari semangat konsep geopark, yakni masyarakat lokal menjadi pengelola.

Belajar dari apa yang dilakukan RKI di geosite Silahisabungan, masyarakat sebenarnya tidak susah diajak untuk terlibat dalam membangun kegiatan berbasis geopark, hanya saja cara kerjanya, haruslah menjadikan masyarakat lokal sebagai subjek pengembangan daerahnya. Desa Silalahi 3 dan Paropo sebelumnya jarang dikunjungi pengunjung, namun kini menjadi tempat favorit kalangan muda menikmati wisata alam seperti kemping, dan langsung dikelola masyarakat lokal.

Sesuai dengan pengusulan GKT menuju GGU, geosite Silahisabungan memiliki potensi lengkap dari sisi alam, budaya dan hayati yang dapat diunggulkan. Oleh karena itu, sangat penting mendapat dukungan penuh dari pemerintah, baik pusat, provinsi dan daerah. Masyarakat lokal harus mendapat pendampingan dan penyuluhan bagaimana memaksimalkan potensi daerahnya dengan prinsip-prinsip berkelanjutan. Jika pemerintah serius dalam pengembangan geosite Silahisabungan, itu sangat potensial dalam meningkatkan pendapatan asli daerah (PAD).

Sebagai studi awal, penelitian ini sangat perlu dikembangkan lebih jauh untuk mendapatkan gambaran lebih utuh tentang pengembangan sebuah geosite. Geosite Silahisabungan ini nantinya bisa menjadi model bagaimana mengelola dan membenahi sebuah geosite oleh masyarakat lokal, sehingga tujuan geopark tercapai maksimal.

\section{DAFTAR PUSTAKA}

Affandi, Oding, 2002, Tinjauan Antropologi Pelibatan Masyarakat Lokal Dalam Pembangunan Kehutanan, Universitas Sumatera Utara, Medan

Adiputra, Julio, 2017, Pengaruh Geopark Kaldera Toba terhadap Pendapatan Masyarakat Pelaku Ekonomi di Kabupaten Toba Samosir, Yogyakarta: Skripsi, Universitas Gadjah Mada

Chesner, Craig A., 2011, The Toba Caldera Complex, Quaternary International,doi:10.1016/j.quaint.2011.09.025. 
Guidelines and Criteria for National Geoparks seeking UNESCO's assistance to join the Global Geoparks Network (GGN), http://www.globalgeopark.org/UploadFiles/2012_9_6/GGN2010.pdf, Diakses 15 Agustus 2018

Guidelines and Criteria for National Geoparks seeking UNESCO's assistance to join the Global Geoparks Network http://www.globalgeopark.org/portals/1/documents/2008ggn guidelinesjuneendorsed.pdf, Diakses 15 Agustus 2018

Kompas, 2011, "Ekspedisi Cincin Api Kompas: Toba Mengubah Dunia,” Jakarta: Harian Kompas.

Kompas, 2011, “Ekspedisi Cincin Api Kompas: Toba Mengubah Dunia,” Jakarta: Kompas TV.

Mewujudkan Tao Silalahi Sebagai Tujuan Wisata Geopark Kaldera Toba, http://sumut.pojoksatu.id/2016/12/05/mewujudkan-tao-silalahi-sebagai-tujuanwisatageopark-kaldera-toba/ Diakses 12, Agustus 2018

Mengintip Potensi dan Peluang Silahisabungan, Kabupaten Dairi Menjadi Bagian dari Kawasan Strategis Pariwisata Nasional dan UNESCO Global Geopark, https://disparbuddairi.com/mengintip-potensi-dan-peluang-silahisabungankabupaten-dairi-menjadi-bagian-dari-kawasan-strategis-pariwisata-nasional-danunesco-global-geopark/, diakses 26 Juni 2019.

Rachmat, Heryadi, 2011, Geowisata Nusa Tenggara Barat, IAGI Pengda Nusa Tenggara, Nusa Tenggara Barat.

Riddell, B., 2004, Research for Development: A Practical Guide by Sophie Laws with Caroline Harper and Rachel Marcus, JOURNAL OF DEVELOPMENT STUDIES LONDON- 40: 185.

Suwardi, Sofyan, dkk, 2016, Pembangunan dan Pengembangan Kawasan Geopark Indonesia. Bandung: Badan Geologi, Kementerian Energi dan Sumber Daya Mineral.

Simatupang, Karmel, 2016, Toba Caldera Geopark Discourse: Critical Discourse Analysis of the CSO and the Government in North Sumatra Province of Indonesia, Taiwan: Thesis, Tunghai University. 